\title{
Analysis of infrastructural forest data with GIS-tools
}

\author{
Ekaterina S. Podolskaia * \\ Center for Forest Ecology and Productivity of the Russian Academy of Sciences (CEPF RAS), Laboratory of Forest Ecosystems \\ Monitoring, ekaterina.podolskaia@gmail.com \\ * Corresponding author
}

Keywords: forest infrastructure, forest roads, Open Source, transport modelling, forest fires, forest resources

\begin{abstract}
:
Infrastructural data analysis is associated with the constant increase in the data complexity in time and space. Forest management and infrastructural forest data in Russia have all these characteristics. The tasks of transport logistics and effective navigation to access the forest fires and forest resources by ground means for the purposes of their protection and use, assessment and forecasting are among the most important ones. An important general practice for the forest industry in Russia is using digitized sheets of topographic maps, satellite imagery and forest management maps and tablets, dealing with the road network data of different quality and sources.
\end{abstract}

Research on transport modeling and forest infrastructure is carried out by Russian specialized educational and scientific, including academic, institutions. Center for Forest Ecology and Productivity of the Russian Academy of Sciences (CEPF RAS) studies ecology and productivity of forests in Russia, their ecosystem functions, resources and environmental potential (http://cepl.rssi.ru/en/about-the-centre/) and has a "Transportation Task" research group (http://cepl.rssi.ru/en/transport-modeling/) within the Laboratory of Forest Ecosystems Monitoring. An "Open”-research direction extends the activities of the "Transportation Task" group by implementing Open Data and Open Source-tools, namely OSM and QGIS with its plugins (Podolskaia, 2020; Podolskaia, 2021).

Within the scope of new tasks, we estimate existing transport systems consisting of public roads, forest roads and cleanings used for timber's export (Podolskaia et al., 2020a). Forest roads standards play an important role in the forest management, there is an example for the accessing of forest fires in Turkey (Akay et al., 2021) in our collaborative projects. From the methodological point of view we have moved from the accessibility analysis of forest fires (Podolskaia et al., 2019; Podolskaia et al., 2020b) to the analysis of forest resources'spatial location (Podolskaia et al., 2020c). By analyzing actual forest resources' accessibility, which takes into account types and conditions of roads, time and traffic speed, length of ground routes, as well as location of fire stations and settlements we propose some forest management solutions or scenarios at the regional scale of Russia.

Information and GIS technologies, the use of data services, and Open Source developments are the basis of modern forestry transport research like any other applied geoinformation industry. Geodata for the public and forest roads, the volume and quality of the accumulated datasets continue to be essential for the methodological and technological solutions. The role of Open Source tools will only grow and provide more alternatives when comparing functionality to the commercial products.

\section{Acknowledgements}

The study was carried out as a part of CEPF's theme "Methodical approaches to assess the structural organization and functioning of forest ecosystems", state registration number AAAA-A18-118052590019-7.

\section{References}

Akay A. E., Podolskaia E. S., Uçar Z., 2021. Effects of improving forest road standards on shortening the arrival time of ground-based firefighting teams accessing to the forest fires. Eur $J$ Forest Eng, 7(1), pp. 32-38. https://doi.org/10.33904/ejfe.952174

Podolskaia E., 2020. Basics of working in Open Source QGIS: geodata, coordinates, functionality, data quality control, map design and web-publishing. Manual, Lab-publisher, 52 p. (in Russian).

Podolskaia E. S., 2021. Review of Open Source QGIS forestry plugins. Forest Science Issues, Vol. 4, No. 2, pp. 1-11. DOI 10.31509/2658-607x-202142-1 (in Russian). 
Podolskaia, E., Ershov, D., and Kovganko, K., 2019. GIS-analysis of ground transport accessibility of fire stations at regional scale, Abstr. Int. Cartogr. Assoc., 1, 301, https://doi.org/10.5194/ica-abs-1-301-2019

Podolskaia E., Ershov D., Kovganko K., 2020a. Comparison of data sources on transport infrastructure for the regional forest fire management// Reyer, C., Bilogub, M., Mahnken, M., Gutsch, M., Kruger, K., Ramming, A., Reineking, B., Seidl, R., Schelhaas, M.-J., Makela, A., Verkerk, H. (Eds.) (2020): Managing forests in the $21^{\text {st }}$ century: Book of abstracts, Managing forests in the $21^{\text {st }}$ century, Conference at the Potsdam Institute for Climate Impact Research (Potsdam 2020), 59 p. https://doi.org/10.2312/pik.2020.002

Podolskaia E., Ershov D., Kovganko K., 2020b. Automated construction of ground access routes for the management of regional forest fires. J. For. Sci., 66, pp. 329-338. https://doi.org/10.17221/59/2020-JFS

Podolskaia, E., Ershov, D. and Kovganko, K., 2020c. GIS-Approach to estimate ground transport accessibility of forest resources (case study: Novosibirsk region, Siberian federal district, Russia). Journal of Geographic Information System, 12, pp. 451-469. doi: 10.4236/jgis.2020.125027 